\title{
Certificate course in healthcare waste management: An overview
}

\author{
Reema Kumari ${ }^{1}$, Anshita Singh ${ }^{2}$ \\ ${ }^{1}$ Associate Professor and Programme Incharge IGNOU-CHCWM , Department of Community Medicine and Public health; \\ ${ }^{2}$ Phd.Scholar; King Georges Medical University, Lucknow, India.
}

\section{Letter to Editor}

In these times of heightened environment consciousness, addressing the issue of proper healthcare waste disposal is of paramount concern not only for environmentalists or other members of the health sector but also for the whole of society. ${ }^{1}$ The concern for healthcare waste management has been felt globally with the rise in deadly infections such as AIDS, hepatitis and other blood-borne infections. ${ }^{1}$ Epidemiological studies show that exposure to pollutants from medical waste incinerators increases the risk of various types of cancers and heart diseases. ${ }^{2}$ Healthcare personnel should be fully aware of the need to exercise caution when handling healthcare waste. All personnel should receive appropriate training to develop awareness on the health, safety and environmental issues relating to healthcare waste. ${ }^{3}$

King George's Medical University, India was selected to be a priority site for the Global Environment Facility (GEF)/Ministry of Environment and Forest (MoEF)/ United Nations Development Program (UNDP) Project which was initiated in May 2010. ${ }^{4}$ The GEF-financed MoEF project, supported by the UNDP, seeks to demonstrate the best practices and non-incineration technologies for bio-medical waste management to avoid environmental release of dioxins and mercury. With the establishment of this project, a Certificate Course in Healthcare Waste Management (CHCWM) was seen as important component. The Indira Gandhi National Open University (IGNOU), New Delhi, India in active collaboration with the World Health Organization (WHO) South-East Asia Region, has developed and launched a six-month certificate programme in healthcare waste management through a network of Study Centers all over India ${ }^{5}$ and therefore a Study Center for this Programme is created in the Department of Community Medicine and Public Health, King George's Medical University, Lucknow. ${ }^{6}$

The Certificate Programme has been developed with the objective to equip the learner with the knowledge and skills to manage healthcare waste effectively and safely, and also safeguard the community against the adverse health impact of healthcare waste. ${ }^{6}$ This course is being provided to the doctors, nurses, paramedics, and staff of the institutions who are involved in the Bio-medical Waste Management System.
CHCWM is the distance learning 6-month certificate programme having 8 blocks of self learning material, 6 days of classes (including field visits), teleconferencing sessions including audio and video cassettes, and two assignments and one project report which are mandatory for the course. Theory classes are taken by the experts in the following fields: (a) Fundamentals: understanding our environment, (b) Healthcare waste: definitions, the need for sound healthcare waste management, the current status of healthcare waste management legislation in SEAR countries, and (c) Healthcare waste management: concepts, technologies and the training of practical aspects of health care waste management, systems and technologies in healthcare waste management, healthcare waste management and emerging issues, and the training manual for waste handlers. A participant has to pass an end of term written examination for two papers conducted through IGNOU, along with the assessment of assignments and project work at the study centre.

Until now, more than 60 Healthcare Personnel from the institution have been registered for this course and have successfully completed and are contributing actively to the training, monitoring and management of the healthcare waste practices of the hospital.

The Global Project Team of the United Nations Development Programme /GEF, in cooperation with the WHO \& Healthcare Without Harm has recognized King George's Medical University, Lucknow, Uttar Pradesh, as a Role Model Hospital for its commitment and dedication to excellence in environmentally sound healthcare waste management practices..$^{1,7,8}$ The project has helped to promote the best practices in healthcare waste management in a hospital and has reduced the amount of infectious waste in the hospital by $80 \%{ }^{8}$ Training in proper segregation, transportation and treatment of bio-medical waste has also helped in reducing the health and environment risks through bio-medical waste. $^{8}$ The hospital also earns INR 1800,000 (US\$ $32,700)$ annually through recycling the hospital waste. ${ }^{8}$

India has taken many steps over the past few decades to address the pollution caused by healthcare waste.

Correspondence: Dr. Reema Kumari, Associate Professor and Programme Incharge IGNOU-CHCWM , Department of Community Medicine and Public Health, King Georges Medical University, Lucknow, India. E-mail: reema_tua05@yahoo.co.in.

South East Asia Journal of Public Health 2013;3(1):72-73. C 2013 Kumari \& Singh, publisher and licensee Public Health Foundation Bangladesh. This is an Open Access article which permits unrestricted non-commercial use, provided the original work is properly cited. 
However, only just over $50 \%$ of the country's 84,809 hospitals and healthcare facilities properly treat their waste and effectively segregate infected waste from non -infected waste. ${ }^{8}$ The wider implementation of such an innovative program would increase the knowledge, skill and the capacity of the public health workforce to manage hospital waste, and would effectively help to establish a model not only for India, but also for other countries in the region.

\section{References}

1. Kumari R, Srivastava K, Wakhlu A, Singh A. Establishing biomedical waste management system in Medical University of India - A successful practical approach. Clin epidem Global Health 2013 (In press).

2. Thompson J, Anthony H. The Health Effects of Waste Incinerators. 4th Report of the British Society for Ecological Medicine. Second Edition. June 2008.

3. Pruss A, Giroult E, Rushbrook P. Safe management of wastes from health-care activities (training). Geneva: World Health Organization, 1999.
4. Kumari R, Nischal A, Wakhlu A. A success story, King George's Medical University, Lucknow, India. Bio-medical Waste Management Bulletin 2012;1:1.

5. Prüss A, Emmanuel J, Rushbrook P, Zghondi R, Stringer R, Pieper U, et al. Safe management of wastes from health-care activities: Second edition. Geneva: World Health Organization, 2013.

6. IGNOU-Certificate course in Healthcare Waste Management (CHCWM)-Education Programme. http://www.kgmu.org/download/currentnews/ ignou course.pdf (accessed June 2013)

7. King George's Medical University, India. http:// w w w. y o u t u b e. c o m/ w a t c h? $\mathrm{v}=\mathrm{koX}$ rieADb8I\&feature $=$ player embedded (accessed June 2013)

8. UNDP. 'Health Without Harm': Reducing Risk from Healthcare Waste in India. http:// www.undp.org/content/india/en/home/ourwork/ environmentandenergy/successstories/healthwithout-harm/(accessed June 2013) 